\title{
Indian Takeovers: A Residual Income Approach to Analyse Value Creation for the Acquirer
}

\author{
Anjala Kalsie* and Jappanjyot Kaur Kalra**
}

\begin{abstract}
The objective of the paper is to test financial performance of major merger and acquisition deals done by Indian companies in the past. The traditional accounting methodologies do not sufficiently address the key issue that whether mergers and acquisitions have a positive value creation for the acquirer and hence, is a positive NPV proposition or not. The paper employs residual income approach for valuing, and comparing the present value of the acquirer's future earnings before the acquisition, with those that actually result following the takeover. The cost of the acquisition, the acquirer's cost of capital, and the earnings have been taken into account. The residual income approach is used for evaluating a few major Indian takeovers during 2000-10. Using the traditional accounting method, it was observed that acquisitions result in a significant or marginal decline in profitability. However, the results using the residual income approach shows that the fundamental valuation of acquirers is significantly lower after the acquisition than it is before the acquisition.
\end{abstract}

Keywords: Merger and acquisition, Residual income approach, Financial performance.

\subsection{Introduction}

In the lifecycle of companies, a takeover is an important event. They are done for several reasons like increasing sales, diversification, decreasing competition, gaining economies of scale, operational synergies, etc. Each decision has a unique impact on the strategy or roadmap of a company's success. The financial impact of corporate deals still remains one of the most important research areas of industrial economics. But the question still remains that whether takeovers improve financial performance of acquirers or not.

*Assistant Professor, Faculty of Management Studies, University of Delhi.

**Research Scholar, Faculty of Management Studies, University of Delhi. 
2 | MUDRA: Journal of Finance and Accounting, Vol. 2, Issue 1

Accounting studies have been used in the past to understand whether financial health of the company improves after acquisition. This evidence is mixed with a small number of studies showing improvements in profitability, but the majority showing no improvement. Event studies examine the stock market's short-term reaction to the takeover announcement. These event studies show significant gains for target shareholders, and no gains or losses for acquiring shareholders, but significant gains overall. The much smaller number of event studies, which examine the long run share returns following acquisition find evidence of significantly negative losses. The interpretation of these stylised facts varies considerably. Some authors claim that the methodology used to measure long run share returns is not reliable and that takeovers create value both in terms of profits and short run share price gains (Andrade, Mitchell and Stafford 2001). In contrast, others argue that the long run negative share returns reflect overvaluation of takeovers at the time of announcement, which ultimately do not improve profits and destroy shareholder value (Tichy, 2002).

From a financial theory point of view, a key question is whether the present value of the financial benefits from acquisition is greater than the present value of the costs, including the initial investment. The issue here is whether the marginal return from acquisition is greater than the marginal cost. However, neither the event study nor accounting study approaches are designed to address this key issue. The stock market reaction to a takeover bid reflects many factors, and not just the marginal impact of acquisition. The accounting studies on the other hand do not explicitly account for the cost of the acquisition, the time value of money, or profits earned beyond a limited postacquisition period.

During the last decade, accounting research has re-explored fundamental approaches to corporate valuation. In this spirit, models based on residual income have been developed, and attained a widespread use in practical valuation settings. In this paper we use the residual income approach to develop a metric for empirical evaluation of the financial performance of takeovers that is consistent with fundamental valuation theory and that hence overcomes some of the deficiencies of the event and accounting performance studies. In particular, the paper estimates the fundamental valuation of the bidder before the acquisition and compares this valuation with the fundamental valuation following the acquisition. If takeovers create fundamental value, then the latter should be greater than the former.

\subsection{Literature Review}

In the context of evaluating the shareholder value in a merger and acquisition, the following research papers have been reviewed. Andrade, Mitchell and Stafford 
(2001) argued that following the merger transactions, a negative drift in acquiring firm stock prices is present, which would entail that the gains from mergers are overstated or shown to be non-existent. Also, the underlying sources of the gains from mergers could not been identified because of the different motivations for an acquisition. The claim that mergers create value stems from the finding that all of the gains from mergers seem to accrue to the target firm shareholders. The mergers deal done with the assumption that in an efficient economy, mergers would happen for the right reasons and the results would meet the expectations of the parties, on an average during negotiations. However, the fact that mergers do not seem to benefit acquirers provides reason to worry about this analysis.

Myers and Majluf (1984) argue that an acquisition announcement provides a bundle of signals all of which generate information, that is reflected in the security price of the acquiring company. In relation to the event certain signals like the method of payment, the identity of the acquirer, among others provide information about the Merger. For example, studies have shown that acquirers using stock as the method of payment experience lower returns than those using cash. Empirical findings suggest that, during the mergers when the shares of a acquiring company are overvalued by the stock market the acquirers preferably offer stock over Cash.

Alternatively, when a firm acquires any new project that has a positive net present value(NPV), the market value of the firm gets affected with the expectations associated with the NPV are met or not. If a firm is expected to take on high positive NPV projects, then this expectation will be built into value. Even if the new projects taken on by the firm have a positive NPV, there may be a drop in value if the NPV does not meet the high expectations of the stock market. To disentangle the impact on stock prices of these signals and thereby evaluate whether the marginal benefit of the acquisition is greater than the cost is very difficult.

Dickerson, Gibson, and Tsakalotos (1997) propose that the difference between the post-bid performance of the acquirer with the pre-bid performance of the acquirer only. However, whether acquirer performance improves or deteriorates does not tell us whether fundamental value is created. This requires estimation of whether the additional profit returns brought about by the acquisition are greater than the cost of capital. In other words the profitability of the acquirer could be lower following acquisition, but the marginal profitability may be higher than the cost of capital, or vice versa. It is therefore important to compare the marginal profitability associated with the acquisition to the acquirers cost of capital.

Ghosh and Jain (2000) tend to give equal weight to each post-takeover year and propose that however, if the timing of profits is of crucial importance in establishing 
4 | MUDRA: Journal of Finance and Accounting, Vol. 2, Issue 1

whether acquisitions improve fundamental valuation. It is therefore important to weight future profits by the cost of capital to represent the higher value accorded to profits which occur sooner rather than later. Since acquisitions have important effects on capital structure and hence the cost of capital, it is the post-acquisition cost of capital which is relevant here.

In both the above types of studies, the profitability measure is adjusted for factors such as industry and size. Takeovers are classified as successful if they outperform the expected performance of similar size and/or industry counterfactuals. However, this adjustment says nothing about whether the relative performance is sufficient in absolute terms. A return that is worse than that of the control firms can still be satisfactory compared to the cost of capital and vice versa.

\subsection{Objectives and Hypothesis}

The objective of this paper is to evaluate financial performance of some of the major Indian takeovers which happened during 2000-2010 where an Indian firm is the acquirer. Further, we also intend to understand if takeovers really create value for the shareholders of the acquiring firm.

Residual income (RI), or economic profit, is the net income of a firm less a charge that measures stockholders' opportunity cost of capital. The rationale for the residual income approach is that it recognises the cost of equity capital in the measurement of income. This concept of economic income is not reflected in traditional accounting income, whereby a firm can report positive net income but not meet the return requirements of its equity investors. Accounting net income includes a cost of debt (i.e., interest expense), but does not reflect dividends or other equity capital-related funding costs. This means that accounting income may overstate returns from the perspective of equity investors. Conversely, residual income explicitly deducts all capital costs.

The testing of the residual income approach is applied on the following Indian acquisitions:

1. Tata Steel - Corus Acquisition

2. ONGC - Imperial Energy Acquisition

3. United Spirits - Whyte \& Mackay Group Acquisition

4. Hindalco-Novelis Acquisition

5. Indian Hotels - Ritz Carlton Acquisition

6. Havells - Sylvania Acquisition 


\subsection{Methodology}

\subsection{Traditional accounting approach}

To examine the impact of merger using traditional accounting performance technique, return on equity profit measure has been used. Comparing the post-takeover performance of the bidder with this pre-takeover benchmark provides a measure of the change in performance. In this analysis, three or four years before and after the merger or acquisition has been used. By comparing pre and post-merger data for RoE, we can understand if the company has become more profitable or has seen a decline in profitability.

\subsection{Residual income approach}

A stock's fundamental value is typically defined as the present value of expected future dividends based on all currently available information.

$\mathrm{V}_{\mathrm{t}}=$ Stock intrinsic value at time $\mathrm{t}$

$$
V t=\sum_{i=1}^{\infty} \frac{E_{t}\left(D_{t+i}\right)}{\left(1+r_{e}\right)^{i}}
$$

$E_{t}\left(D_{t+1}\right)=$ expected future dividends for period $t+1$

$r_{e}=$ cost of equity capital

The intrinsic value can be rewritten as the reported book value, plus an infinite sum of discounted residual income:

$$
\begin{aligned}
& V t=B_{t}+\sum_{i=1}^{\infty} \frac{E_{t}\left[\left(N I_{t+i}-\left(r_{e} B_{t+i-1}\right)\right)\right]}{(1+r e)^{i}} \\
& V t=B_{t}+\sum_{i=1}^{\infty} \frac{\left.E t\left[\left(R O E_{t+i}-r_{e}\right) B_{t+i-1}\right)\right]}{\left(1+r_{e}\right)^{i}}
\end{aligned}
$$

where

$\mathrm{B}_{\mathrm{t}}=$ book value at time $\mathrm{t}$

$\mathrm{E}_{\mathrm{t}}[]=$. Expectation at time $\mathrm{t}$

$\mathrm{NI}_{\mathrm{t}+1}=$ Net income for period $\mathrm{t}+1$

$\mathrm{ROE}_{\mathrm{t}+1}=$ after tax return on book equity for period $\mathrm{t}+1$

The above equation is identical to a dividend discount model, but articulates firm value in terms of accounting numbers. It thus relies on the same theory and has same theoretical limitations as the dividend discount model.

The residual income approach is used to examine whether the fundamental valuation of the acquiring company is greater after the acquisition than it is before. The 
difference in valuations, or what we term value creation (VC), is the marginal change in residual income as follows:

$$
V C=\sum_{i=1}^{\infty} \frac{\left(R O E_{t}-r_{e}\right) B_{t-1}}{\left(1+r_{e}\right)^{t}}-\sum_{i=1}^{\infty} \frac{E_{t}\left(R O E_{t}-r_{e}\right) B_{t-1}}{\left(1+r_{e}\right)^{t}}
$$

The left-hand term is based on actual ROEs, whereas, the right hand term is based on expected ROEs. For the takeover to create value, VC must exceed zero. But this equation has to constraints:

- Firstly, it is not empirically possible to measure residual income for an infinite period following acquisition. Because most previous takeover studies cover a time period of 5 years following acquisition, we select a post-takeover period equal to five years to measure actual residual income. We therefore require an estimate of future value creation beyond this 5-year period for the acquirer.

- Secondly, it is not possible to measure residual income for the buyer as if no acquisition took place. One possible way to measure both these variables is with market values.

One can further argue that the market value minus equity book value at the end of the 5-year post-acquisition period is a reasonable proxy for the remaining value creation of the acquirer. $12 \mathrm{We}$ therefore propose the following evaluation procedure to measure value creation:

$$
V C=\sum_{i=0}^{\infty} \frac{\left(R O E_{t}-r_{e}\right) B_{t-1}}{\left(1+r_{e}\right)^{t}}+\frac{\left[M\left(B_{4}\right)-B_{4}\right]}{\left(1+r_{e}\right)^{4}}-\left[M\left(B_{0}\right)-B_{0}\right]
$$

Where $\mathrm{M}(\mathrm{B})$ is the market value of shareholder's equity. The first component indicates the actual value creation for post-acquisition years zero through four. The second component reflects the expected marginal value creation beyond year four. The third component is the pre-acquisition value premium, which expresses the amount of value generation that was expected before the takeover. In order to compare the value creation measure across acquirers of different size, each component is divided by the pre-bid market value of the acquiring firm.

\subsection{Adjusting the residual income model for violations of clean surplus accounting}

If the transaction is accounted for using the merger method where the two parties accounts are added together without any goodwill being capitalised, the value creation measure needs to include a deduction for the goodwill paid. For acquiring firms that do not capitalise goodwill for further acquisitions in the post-takeover period, the present 
value of further goodwill that is not capitalised is subtracted from the value creation measure. These two deductions for goodwill is adjusted as follows:

$$
\begin{aligned}
V C=\frac{\sum_{i=0}^{4} \frac{\left(R O E_{t}-r_{e}\right) B_{t-1}}{\left(1+r_{e}\right)^{t}}}{M\left(B_{0}\right)}+\frac{\frac{\left[M\left(B_{4}\right)-B_{4}\right]}{\left(1+r_{e}\right)^{4}}}{M\left(B_{0}\right)}-\frac{G W_{0}}{M\left(B_{0}\right)}-\frac{\sum_{i=1}^{4} \frac{G W_{1-4}}{\left(1+r_{e}\right)^{t}}}{M\left(B_{0}\right)} \\
-\frac{\left[M\left(B_{0}\right)-B_{0}\right]}{M\left(B_{0}\right)}
\end{aligned}
$$

where $\mathrm{GW}_{0}$ is goodwill not capitalised for the year of acquisition, and $\mathrm{GW}_{1-4}$ is goodwill not capitalised for other acquisitions during the 5 year period.

The first component in this equation will be referred to as residual income or RI. The second and last components will be referred to as the value premiums or VP. The third and fourth components will be referred to as goodwill non-capitalised or GW.

Finally, to control for other problems of dirty surplus accounting which occur following acquisition such as extraordinary items and write-downs to fair values (Chatterjee and Meeks 1996), we employ a further measure of residual income. Rather than trying to incorporate such violations individually, we employ an all-inclusive residual income measure defined as:

$$
\operatorname{ROEAI}_{t}=\frac{\left(B_{t}-B_{t-1}+D_{t}-S_{t}\right)}{B_{t}}
$$

where Dt is dividends and St is share issues. This all-inclusive ROE measure (ROEAI) should be used in the first term of Eq. (7) instead of the ROE defined above. When the all-inclusive measure is used there is no need to adjust for goodwill not capitalised, and the goodwill adjustments are excluded from the calculations. This first term is henceforth referred to as the residual income all-inclusive measure or RIAI. VCAI is reffered as value creation measure using the all-inclusive residual income method.

\subsection{Results and Analysis}

\subsection{Tata Steel - Corus Acquisition}

Tata Steel, formerly known as TISCO (Tata Iron and Steel Company Limited), was the world's 56th largest and India's 2nd largest steel company with an annual crude steel capacity of 3.8 million tonnes. Corus was formed from the merger of Koninklijke Hoogovens N.V. with British Steel. Corus Group turnover for FY2005 was £10.142 billion. The details of Tata Steel's Corus acquisition are given in Table 1. 
8 | MUDRA: Journal of Finance and Accounting, Vol. 2, Issue 1

Table 1: Tata Steel - Corus Acquisition

\begin{tabular}{|l|l|}
\hline Acquirer & Tata Steel Ltd \\
\hline Target & Corus Group Ltd \\
\hline Deal Size (in INR Crores) & 57868.74 \\
\hline Payment Type & Cash \\
\hline Announce Date & $17 / 10 / 2006$ \\
\hline Completion Date & $5 / 4 / 2007$ \\
\hline
\end{tabular}

Based on the traditional accounting approach, the return on equity of the acquirer pre and post-merger has been mentioned in Table 2 below.

Table 2: Return on Equity

\begin{tabular}{|c|c|}
\hline Year & Return on Equity \\
\hline 2004 & $45.35 \%$ \\
\hline 2005 & $60.02 \%$ \\
\hline 2006 & $41.70 \%$ \\
\hline 2007 & $35.40 \%$ \\
\hline Average (pre-acquisition) & $\mathbf{4 5 . 6 2 \%}$ \\
\hline Median (pre-acquisition) & $\mathbf{4 5 . 3 5 \%}$ \\
\hline 2009 & $18.10 \%$ \\
\hline 2010 & $15.41 \%$ \\
\hline 2011 & $16.37 \%$ \\
\hline 2012 & $13.45 \%$ \\
\hline Average (post-acquisition) & $\mathbf{1 5 . 8 3 \%}$ \\
\hline Median (post-acquisition) & $\mathbf{1 5 . 8 3 \%}$ \\
\hline
\end{tabular}

Based on the residual income approach, the resulting value creation as a percentage of the market value of the acquirer one year before the acquisition is as given in Table 3 .

Table 3: Residual Income Approach

\begin{tabular}{|l|l|l|}
\hline Residual Income & RI & $\mathbf{3 8 . 4 5 \%}$ \\
\hline Residual Income all inclusive & RIAI & $33.32 \%$ \\
\hline Value premium in year 0 & $\mathrm{VP}_{0}$ & $45.99 \%$ \\
\hline Value premium in year 4 & $\mathrm{VP}_{4}$ & $-18.68 \%$ \\
\hline Goodwill not capitalized & $\mathrm{GW}$ & $11.81 \%$ \\
\hline Value Creation & $\mathrm{VC}$ & $\mathbf{- 3 8 . 0 4 \%}$ \\
\hline Value creation all-inclusive & VCAI & $\mathbf{- 3 1 . 3 5 \%}$ \\
\hline
\end{tabular}


Based on the accounting approach, one can observe that the company has shown decline in profitability as the return on equity value for Tata Steel has decreased and hence, the acquirer has not been better off by acquiring Corus Group.

Based on the residual income approach, it has been established that the value created in the acquisition has been destroyed completely and it has led to a decline in the shareholder value and probably Tata Steel would have been better off had they not acquired Corus Group.

\subsection{ONGC - Imperial Energy Acquisition}

Oil and Natural Gas Cooperation Limited (ONGC) is an Indian multinational oil and gas company headquartered in Dehradun. It produces $69 \%$ of India's crude oil and $62 \%$ of its natural gas. Imperial Energy Cooperation is a British-based petroleum exploration and business operating in Siberia. It is headquartered in Leeds, England. The details of the acquisition are given in Table 4.

Table 4: ONGC - Imperial Energy Acquisition

\begin{tabular}{|l|l|}
\hline Acquirer & Oil and Natural Gas Cooperation Limited \\
\hline Target & Imperial Energy Cooperation \\
\hline Deal Size (in INR Crores) & 11436.32 \\
\hline Payment Type & Cash \\
\hline Announce Date & $26 / 8 / 2008$ \\
\hline Completion Date & $9 / 3 / 2009$ \\
\hline
\end{tabular}

Based on the traditional accounting approach, the return on equity of the acquirer pre and post-merger has been mentioned in Table 5 below.

Table 5: Return on Equity

\begin{tabular}{|c|c|}
\hline Year & Return on Equity \\
\hline 2006 & $26.74 \%$ \\
\hline 2007 & $27.00 \%$ \\
\hline 2008 & $25.20 \%$ \\
\hline Average (pre-acquisition) & $\mathbf{2 6 . 3 1 \%}$ \\
\hline Median (pre-acquisition) & $\mathbf{2 6 . 7 4 \%}$ \\
\hline 2010 & $20.20 \%$ \\
\hline 2011 & $20.48 \%$ \\
\hline 2012 & $23.87 \%$ \\
\hline 2013 & $17.63 \%$ \\
\hline Average (post-acquisition) & $\mathbf{2 0 . 5 5 \%}$ \\
\hline Median (post-acquisition) & $\mathbf{2 0 . 4 8 \%}$ \\
\hline
\end{tabular}


Based on the residual income approach, the resulting value creation as a percentage of the market value of the acquirer one year before the acquisition is as given in Table 6 .

Table 6: Residual Income Approach

\begin{tabular}{|l|l|l|}
\hline Residual Income & RI & $\mathbf{2 1 . 9 6 \%}$ \\
\hline Residual Income all inclusive & RIAI & $23.11 \%$ \\
\hline Value premium in year 0 & $\mathrm{VP}_{0}$ & $66.33 \%$ \\
\hline Value premium in year 4 & $\mathrm{VP}_{4}$ & $48.61 \%$ \\
\hline Goodwill not capitalized & $\mathrm{GW}$ & $1.77 \%$ \\
\hline Value Creation & $\mathrm{VC}$ & $\mathbf{2 . 4 8 \%}$ \\
\hline Value creation all-inclusive & VCAI & $\mathbf{5 . 3 9 \%}$ \\
\hline
\end{tabular}

Based on the accounting approach, one can observe that the company has shown decline in profitability as the return on equity value for ONGC has decreased and hence, the acquirer has not been better off by acquiring Imperial Energy Cooperation.

Based on the residual income approach, it has been established that the acquisition has created value for the shareholders and it has led to an increase in the returns for shareholders value and hence ONGC been able to create some success with its merger with Imperial Energy.

\subsection{United Spirits - Whyte \& Mackay Group Acquisition}

United Spirits Limited, is an Indian alcoholic beverages company, and the world's second-largest spirits company by volume. Whyte \& Mackay is a Scottish company producing alcoholic beverages. It was founded in 1844 and is based in Glasgow. Whyte \& Mackay's self-branded whisky holds about 3 per cent of the UK whisky market. The details of the acquisition are provided in Table 7.

Table 7: United Spirits - Whyte \& Mackay Group Acquisition

\begin{tabular}{|l|l|}
\hline Acquirer & United Spirits Limited \\
\hline Target & Whyte \& Mackay Group Limited \\
\hline Deal Size (in INR Crores) & 4797.39 \\
\hline Payment Type & Cash \\
\hline Announce Date & $16 / 5 / 2007$ \\
\hline Completion Date & $16 / 5 / 2007$ \\
\hline
\end{tabular}


Based on the traditional accounting approach, the return on equity of the acquirer pre and post-merger has been mentioned below in Table 8 .

Table 8: Return on Equity

\begin{tabular}{|c|c|}
\hline Year & Return on Equity \\
\hline 2006 & $4.69 \%$ \\
\hline 2007 & $44.15 \%$ \\
\hline 2008 & $18.58 \%$ \\
\hline Average (pre-acquisition) & $\mathbf{2 2 . 4 7 \%}$ \\
\hline Median (pre-acquisition) & $\mathbf{1 8 . 5 8 \%}$ \\
\hline 2010 & $9.56 \%$ \\
\hline 2011 & $7.80 \%$ \\
\hline 2012 & $6.24 \%$ \\
\hline 2013 & $5.23 \%$ \\
\hline Average (post-acquisition) & $\mathbf{7 . 2 1 \%}$ \\
\hline Median (post-acquisition) & $\mathbf{7 . 2 1 \%}$ \\
\hline
\end{tabular}

Based on the residual income approach, the resulting value creation as a percentage of the market value of the acquirer one year before the acquisition is as given in Table 9 .

Table 9: Residual Income Approach

\begin{tabular}{|l|l|l|}
\hline Residual Income & RI & $\mathbf{- 1 . 9 7 \%}$ \\
\hline Residual Income all inclusive & RIAI & $-2.26 \%$ \\
\hline Value premium in year 0 & $\mathrm{VP}_{0}$ & $86.61 \%$ \\
\hline Value premium in year 4 & $\mathrm{VP}_{4}$ & $89.04 \%$ \\
\hline Goodwill not capitalized & $\mathrm{GW}$ & $24.44 \%$ \\
\hline Value Creation & $\mathrm{VC}$ & $\mathbf{- 2 3 . 9 8 \%}$ \\
\hline Value creation all-inclusive & VCAI & $\mathbf{0 . 1 7 \%}$ \\
\hline
\end{tabular}

Based on the accounting approach, one can observe that the company has shown a substantial decline in profitability as the return on equity value for United Spirits have decreased substantially and hence, the acquirer has not been better off by acquiring Whyte \& Mackay Group.

Based on the residual income approach, it has been established that the acquisition has created no value for the shareholders in terms of total returns. 
12 | MUDRA: Journal of Finance and Accounting, Vol. 2, Issue 1

\subsection{Hindalco-Novelis Acquisition}

Hindalco Industries Ltd. is an aluminium manufacturing company and is a subsidiary of the Aditya Birla Group. Its headquarters are at Mumbai, Maharashtra, India. It is the flagship company of the Aditya Birla Group in the metals business. Novelis Inc. is an American industrial aluminium company, headquartered in Atlanta, Georgia, United States. Novelis is a leading producer of rolled aluminium and the global leader in beverage can recycling. The details of the acquisition are given in Table 10 below.

\section{Table 10: Hindalco-Novelis Acquisition}

\begin{tabular}{|l|l|}
\hline Acquirer & Hindalco Industries Ltd. \\
\hline Target & Novelis Inc. \\
\hline Deal Size (in INR Crores) & 25206.74 \\
\hline Payment Type & Cash \\
\hline Announce Date & $11 / 2 / 2007$ \\
\hline Completion Date & $18 / 5 / 2007$ \\
\hline
\end{tabular}

Based on the traditional accounting approach, the return on equity of the acquirer pre and post-merger has been mentioned below in Table 11.

Table 11: Return on Equity

\begin{tabular}{|c|c|}
\hline Year & Return on Equity \\
\hline 2005 & $18.31 \%$ \\
\hline 2006 & $19.17 \%$ \\
\hline 2007 & $23.29 \%$ \\
\hline 2008 & $19.16 \%$ \\
\hline Average (pre-acquisition) & $\mathbf{1 9 . 9 8 \%}$ \\
\hline Median (pre-acquisition) & $\mathbf{1 9 . 1 6 \%}$ \\
\hline 2010 & $7.41 \%$ \\
\hline 2011 & $7.42 \%$ \\
\hline 2012 & $7.25 \%$ \\
\hline 2013 & $5.15 \%$ \\
\hline Average (post-acquisition) & $\mathbf{6 . 8 1 \%}$ \\
\hline Median (post-acquisition) & $\mathbf{7 . 3 3 \%}$ \\
\hline
\end{tabular}

Based on the residual income approach, the resulting value creation as a percentage of the market value of the acquirer one year before the acquisition is as given in Table 12. 
Table 12: Residual Income Approach

\begin{tabular}{|l|l|l|}
\hline Residual Income & RI & $\mathbf{- 3 . 7 4 \%}$ \\
\hline Residual Income all inclusive & $\mathrm{RIAI}$ & $6.98 \%$ \\
\hline Value premium in year 0 & $\mathrm{VP}_{0}$ & $13.94 \%$ \\
\hline Value premium in year 4 & $\mathrm{VP}_{4}$ & $-60.39 \%$ \\
\hline Goodwill not capitalized & $\mathrm{GW}$ & $0.00 \%$ \\
\hline Value Creation & $\mathrm{VC}$ & $\mathbf{- 7 8 . 0 7 \%}$ \\
\hline Value creation all-inclusive & $\mathrm{VCAI}$ & $\mathbf{- 6 7 . 3 5 \%}$ \\
\hline
\end{tabular}

Based on the accounting approach, one can observe that the company has shown a drastic decline in profitability of Hindalco and hence, the acquirer has not been better off by acquiring Novelis.

Based on the residual income approach, it has been established that the acquisition has destroyed its value post-merger for the shareholders in terms of total returns and thus, has caused losses to the common shareholders.

\subsection{Indian Hotels - Ritz Carlton Acquisition}

Taj Group the brand for Indian Hotels Company Limited (IHCL), is a chain of hotels and resorts headquartered at Oxford House in Mumbai, which was incorporated in the year 1903 by the founder of the Tata group, Jamshedji Tata. The company is a part of the Tata group, which is one of the India's largest business conglomerates. Taj Group operates over 15 hotels in the UK, USA, Africa, Maldives, Malaysia, Bhutan, Sri Lanka and the Middle East, and 125 hotels across India with the employees over 13000 people in the year 2010. Taj Group also owns a few private islands. The Ritz-Carlton Hotel Company, L.L.C. is the parent company to the luxury hotel chain, named as The RitzCarlton Hotels. Ritz-Carlton operates 84 luxury hotels and resorts in major cities and in 26 countries worldwide. They sold their Boston brand to Indian Hotels Company Limited. The details of the acquisition are laid out in Table 13.

Table 13: Indian Hotels - Ritz Carlton Acquisition

\begin{tabular}{|l|l|}
\hline Acquirer & Indian Hotels Co Ltd \\
\hline Target & Ritz-Carlton (Boston) \\
\hline Deal Size (in INR Crores) & 757.41 \\
\hline Payment Type & Cash \\
\hline Announce Date & $9 / 11 / 2006$ \\
\hline Completion Date & $11 / 1 / 2007$ \\
\hline
\end{tabular}


Based on the traditional accounting approach, the return on equity of the acquirer pre and post-merger has been mentioned below in Table 14 .

Table 14: Return on Equity

\begin{tabular}{|c|c|}
\hline Year & Return on Equity \\
\hline 2006 (pre-acquisition) & $10.71 \%$ \\
\hline 2008 & $19.68 \%$ \\
\hline 2009 & $9.21 \%$ \\
\hline 2010 & $5.34 \%$ \\
\hline 2011 & $4.77 \%$ \\
\hline Average (post-acquisition) & $9.75 \%$ \\
\hline Median (post-acquisition) & $7.27 \%$ \\
\hline
\end{tabular}

Based on the residual income approach, the resulting value creation as a percentage of the market value of the acquirer one year before the acquisition is given in Table 15 .

Table 15: Residual Income Approach

\begin{tabular}{|l|l|l|}
\hline Residual Income & $\mathrm{RI}$ & $2.51 \%$ \\
\hline Residual Income all inclusive & $\mathrm{RIAI}$ & $-2.09 \%$ \\
\hline Value premium in year 0 & $\mathrm{VP}_{0}$ & $77.67 \%$ \\
\hline Value premium in year 4 & $\mathrm{VP}_{4}$ & $29.69 \%$ \\
\hline Goodwill not capitalized & $\mathrm{GW}$ & $0.00 \%$ \\
\hline Value Creation & $\mathrm{VC}$ & $-45.48 \%$ \\
\hline Value creation all-inclusive & VCAI & $-50.08 \%$ \\
\hline
\end{tabular}

Based on the accounting approach, one can observe that the company has shown a slight decline in profitability and hence, the Indian Hotels has not been better off by acquiring Ritz-Carlton (Boston).

Based on the residual income approach, it has been established that the acquisition has destroyed its value post-merger for the shareholders in terms of total returns and thus, has caused losses to the common shareholders.

\subsection{Havells - Sylvania Acquisition}

Havells India Ltd is a billion-dollar-plus electrical equipment company founded in 1958. Havells owns global brands like Crabtree, Sylvania, Concord, Lumiance and has 91 branches/ representative offices with over 6500 professionals in over 50 
countries. Sylvania Electric Products was a U.S. manufacturer of diverse electrical equipment, including at various times radio transceivers, vacuum tubes, semiconductors, and mainframe computers. The details of the acquisition are given in Table 16.

Table 16:1 Havells - Sylvania Acquisition

\begin{tabular}{|l|l|}
\hline Acquirer & Havells India Ltd \\
\hline Target & SLI Sylvania's lighting business \\
\hline Deal Size (in INR Crores) & 1326.60 \\
\hline Payment Type & Cash \\
\hline Announce Date & $13 / 3 / 2007$ \\
\hline Completion Date & $23 / 4 / 2007$ \\
\hline
\end{tabular}

Based on the traditional accounting approach, the return on equity of the acquirer pre and post-merger has been mentioned in Table 17 below. Based on the residual income approach, the resulting value creation as a percentage of the market value of the acquirer one year before the acquisition is given in Table 18.

Table 17: Return on Equity

\begin{tabular}{|c|c|}
\hline Year & Return on Equity \\
\hline 2004 & $41.76 \%$ \\
\hline 2005 & $41.82 \%$ \\
\hline 2006 & $48.14 \%$ \\
\hline 2007 & $46.60 \%$ \\
\hline Average (pre-acquisition) & $\mathbf{4 4 . 5 8 \%}$ \\
\hline Median (pre-acquisition) & $\mathbf{4 4 . 2 1 \%}$ \\
\hline 2009 & $18.14 \%$ \\
\hline 2010 & $22.05 \%$ \\
\hline 2011 & $19.55 \%$ \\
\hline 2012 & $20.71 \%$ \\
\hline Average (post-acquisition) & $\mathbf{2 0 . 1 1 \%}$ \\
\hline Median (post-acquisition) & $\mathbf{2 0 . 1 3 \%}$ \\
\hline
\end{tabular}

Based on the accounting approach, one can observe that the company has shown substantial decline in profitability as the return on equity value for Havells has decreased and hence, the acquirer has not been better off by acquiring SLI Sylvania's lighting business. 
Table 18: Residual Income Approach

\begin{tabular}{|l|l|l|}
\hline Residual Income & $\mathrm{RI}$ & $23.06 \%$ \\
\hline Residual Income all inclusive & $\mathrm{RIAI}$ & $-63.54 \%$ \\
\hline Value premium in year 0 & $\mathrm{VP}_{0}$ & $88.82 \%$ \\
\hline Value premium in year 4 & $\mathrm{VP}_{4}$ & $176.65 \%$ \\
\hline Goodwill not capitalized & $\mathrm{GW}$ & $12.41 \%$ \\
\hline Value Creation & $\mathrm{VC}$ & $\mathbf{9 8 . 4 8 \%}$ \\
\hline Value creation all-inclusive & $\mathrm{VCAI}$ & $\mathbf{2 4 . 2 9 \%}$ \\
\hline
\end{tabular}

Based on the residual income approach, it has been established that the acquisition has created significant value for the shareholders and it has led to an increase in the returns for shareholders value and hence Havells been able to create some success with its merger with Sylvania.

\subsection{Conclusion}

The methodology used in this research for evaluating takeover success measures whether the fundamental valuation of the acquirer is greater after the acquisition than it was beforehand. The paper employs the methodology of residual income approach to fundamental valuation, and differs from traditional accounting studies which are not designed to directly address this issue. The stock market reaction to a takeover bid reflects many factors, such as signaling overvalued stock, as well as the marginal impact of acquisition. Alternatively, accounting studies do not explicitly account for the cost of acquisition and the time value of money. In order to create fundamental value, acquirers must outperform the pre-merger expectations formed by the stock market and exceed the value creation achieved by non-merging control firms.

The methodology is tested on a few major big-ticket takeovers where the acquirer is an Indian firm during 2000-2010. Using the traditional accounting study approach, it has been found out that most of the merger either decrease the return on equity or keeps it unchanged. The results using the residual income approach shows that the fundamental valuation of acquirers is significantly lower after the acquisition than it is before the acquisition. The acquirers' value destruction relative to control firms is sufficiently high and only two out of six deal analysis showed positive value being created. The difference in performance is not driven by lower returns on equity, but instead the deduction of goodwill expenditure, which is not capitalised at the time of acquisition. 
One potential weakness of this approach is the use of market values, since acquirers typically experience negative share returns in the long-run period following acquisition. Future work should therefore estimate the robustness of these results using forecasts of future residual income, which do not rely on market values. Another line of enquiry is which factors have an impact on fundamental value creation. In this regard it is important to examine the impact of the bid premium on fundamental value creation. Given the method used by traditional methods in dealing with goodwill, higher bid premiums are unlikely to have an impact on the accounting performance. However, ceteris paribus, the higher the bid premium the lower the increase in fundamental value of the acquirer. This methodology therefore appears well suited to examine this issue.

\section{References}

Andrade, G., Mitchell, M., \& Stafford, E. (2001). New evidence and perspectives on Acquisitions. Journal of Economic Perspectives, 15: 103-120.

Tichy, G. (2002). What do we know about the success and failure of mergers?. Journal of Industry, Competition and Trade, 1: 347-394.

Dickerson, A.P., Gibson, H.D., \& Tsakalotos, E. (1997). The impact of acquisitions on company performance: Evidence from a large panel of U.K. firms. Oxford Economic Papers, 49: 344-361.

Ghosh, A. \& Jain, P. (2000). Financial leverage changes associated with corporate mergers. Journal of Corporate Finance, 6: 377-402.

Chatterjee, R., \& Meeks, G. (1996).The financial effects of takeover: Accounting rates of return and accounting regulation. Journal of Business Finance and Accounting, 23: 851-868.

Tata Steel Annual Report. (2007-08). p. 186

Tata Steel Annual Report. (2009-10). p. 135

ONGC Annual Report. (2008-09).

United Spirits Annual Report. (2010-11). 
18 MUDRA: Journal of Finance and Accounting, Vol. 2, Issue 1

United Spirits Annual Report. (2011-12).

Indian Hotels Annual Report. (2006-07).

Hindalco Annual Report. (2008-09).

Hindalco Annual Report. (2009-10). 